\title{
Chemical Quality Status of Rivers for the Water Framework Directive: A Case Study of Toxic Metals in North West England
}

\author{
Phil Rowland ${ }^{1, *}$, Colin Neal ${ }^{2}$, Darren Sleep ${ }^{1}$, Colin Vincent ${ }^{1}$ and Paul Scholefield ${ }^{1}$
}

1 Centre for Ecology and Hydrology, Library Ave, Bailrigg, Lancaster, LA1 4AP, UK;

E-Mails: dsleep@ceh.ac.uk (D.S.); cdv@ceh.ac.uk (C.V.); paul1@ceh.ac.uk (P.S.)

2 Centre for Ecology and Hydrology, Benson Lane, Crowmarsh Gifford, Wallingford, Oxfordshire , OX10 8BB, UK; E-Mail: cn@ceh.ac.uk

* Author to whom correspondence should be addressed; E-Mail: apr@ceh.ac.uk; Tel.: +0044-0-152459800; Fax: +0044-0-152461536.

Received: 17 April 2011; in revised form: 27 May 2011 / Accepted: 28 May 2011 /

Published: 14 June 2011

\begin{abstract}
This paper provides data from two years of monitoring of the chemical quality of rivers and streams in North West England from the clean headwaters to polluted rivers just above the tidal reach and covers 26 sites including the Ribble, Wyre and the tributary rivers of the Calder and Douglas. Across the basins that include areas of rural, urban and industrial typologies, data is presented for three of the priority substances in the Water Framework Directive i.e., nickel $(\mathrm{Ni})$, cadmium $(\mathrm{Cd})$, and lead $(\mathrm{Pb})$. Average concentrations are low and well below the Environmental Quality Standards values for all three of these substances. Cadmium and $\mathrm{Pb}$ appear in approximately equal proportions in the dissolved $(<0.45 \mu \mathrm{m})$ and in the acid available particulate fractions $(>0.45 \mu \mathrm{m})$ whilst $\mathrm{Ni}$ occurs predominantly in the dissolved form (92\%). Regional inputs of these metals arise mostly from diffuse sources as the storm-flow concentrations are generally greater than at base-flow condition. Greater concentrations of $\mathrm{Ni}$ are transported at the headwaters and smaller tributary sites under storm flow condition than for the main stream of the Ribble. For $\mathrm{Ni}$, amounts increase as the river proceeds from its headwaters down towards the Ribble and Wyre estuaries, whilst $\mathrm{Cd}$ and $\mathrm{Pb}$ show consistent values throughout the catchment. There is annual cycling of dissolved concentrations of $\mathrm{Cd}, \mathrm{Pb}$ and $\mathrm{Ni}$ for the clean headwater streams that gives maxima during the latter half of the year when the river flow is greater. For the impacted sites the pattern is less distinct or absent. Our estimates
\end{abstract}


suggest that the Ribble estuary receives $550 \mathrm{t} \mathrm{y}^{-1}$ of dissolved $\mathrm{Ni}, 16 \mathrm{t} \mathrm{y}^{-1}$ of dissolved $\mathrm{Cd}$ and $240 \mathrm{t} \mathrm{y}^{-1}$ of dissolved $\mathrm{Pb}$.

Keywords: nickel; cadmium; lead; dissolved; chemical quality; NW England; River Ribble; River Wyre

\section{Introduction}

The Water Framework Directive (WFD) was introduced to achieve protection and sustainable development of water resources in the European Union (EU) countries [1]. Subsequently the EU established Environmental Quality Standards (EQS) for 33 priority substances and other certain pollutants [2]. This includes the trace metals nickel $(\mathrm{Ni})$, cadmium $(\mathrm{Cd})$, lead $(\mathrm{Pb})$ and mercury $(\mathrm{Hg})$ that are potentially quite toxic to aquatic life. The directive sets annual averages and maximum allowable concentrations for inland and other surface waters for the dissolved fraction. More recently, River Basin Management Plans (RBMP) of most of Europe's river basins have been prepared and are at their early stage of implementation [3]. Scientific knowledge is required for further development of RBMPs to facilitate the achievements of good environmental status in surface water bodies. It appears that there is over-reliance on pollution inventory data which leads to a wrong assignment of control measures [4].

Although there have been significant improvements in regional water quality in recent years [5], according to the data in the Environment Agency's database, many of the North West's rivers are still subject to significant sewage and industrial inputs and or/ agricultural runoff [6,7]. Nickel, $\mathrm{Cd}$ and $\mathrm{Pb}$ are widely used in manufactured products and released into the environment from point source discharges, although it is suggested that diffuse pollution could be higher than point sources [8]. Upland peat is regarded as effective sinks of atmospherically deposited lead. The process of peat erosion should be considered when estimating lead outputs from peat-land catchments [9]. Emission of $\mathrm{Ni}, \mathrm{Cd}$ and $\mathrm{Pb}$ in the $\mathrm{UK}$ has declined by approximately $90 \%$ since 1970 as a result of the general fall in coal combustion, improved controls on Municipal Solid Waste incinerators, the use of unleaded petrol and the increased use of cars fitted with catalytic converters [10]. The reduction in atmospheric emissions and the loss of manufacturing industries in recent years should contribute to the reduction of trace metal concentration in rivers. Other possible sources of metals may arise from abandoned metal mines in the catchments. A recent DEFRA/EA program in the UK has recently begun reporting $[11,12]$ and while data is certainly sparse for the studied catchments, there are numerous abandoned mine sites in the upper Ribble which lies on the margin of one of the most productive $\mathrm{Pb}$ orefields in $\mathrm{W}$ Europe. Given recent studies have consistently found large fluxes of metals (notably $\mathrm{Cd}, \mathrm{Pb}$ and $\mathrm{Zn}$ ) associated with such mines elsewhere (from point and diffuse sources), it would be more than feasible that abandoned mines are contributing (in all likelihood to a lesser degree than more productive areas) to the instream metal flux in the upper Ribble in particular.

There are few recent publications that describe the current toxic metals concentrations in UK river systems, but there is background information for the 1990s from a study of the eastern UK rivers [13] and examples of chronic pollution from an earlier era $[14,15]$. The Ribble and Wyre catchments are 
excellent observatories offering a whole range of water qualities and land uses. Ribble is a major river draining into the Irish Sea important for salmon fisheries, water abstraction, and the smaller Wyre catchment is included in the Catchment Sensitive Farming Delivery Initiative. In this paper, a regional assessment of three of the inorganic WFD priority elements of dissolved toxic metals $\mathrm{Ni}, \mathrm{Cd}$ and $\mathrm{Pb}$ in streams and rivers is provided based on a study of two adjacent river basins in the northwest of England, the Ribble and Wyre. Mercury, the other inorganic priority substance with a specified EQS value, is considered elsewhere [16]. These basins are of strategic importance in relation to basin-wide management at the UK and Europe level. Contained within this source to sea study are sites ranging from the clean headwaters of upland rural areas to the lowlands and some historic legacy of Britain's Industrial Revolution and other areas of intensive agriculture. Within Lancashire there is a long history of chemical industry and added pressures from high population and collectively this has led for example to significant contamination to the Ribble estuary and Irish Sea. In remote sites, concentrations may be low and generally under the detection limit of the analytical method [1] unless the most sensitive analytical techniques are applied. Recent improvements in analytical methodology and approach allow the assessment of concentrations of these metals across the range of typologies.

\section{Materials and Methods}

\subsection{Site Characteristics}

The major rivers of the Ribble and Wyre drain to the Irish Sea and both have upland areas of outstanding natural beauty. While the Wyre has only one market town (Garstang) in its lower reaches, the Ribble drains many of the major urban/industrial town of northeast Lancashire (Burnley, Accrington, Blackburn and Wigan). The geology of the Ribble (including the Calder $1,152 \mathrm{~km}^{2}$ ) is predominantly carboniferous age limestone, shale and grit of the Yorkshire Dales and the Trough of Bowland. For the other river basins of the Wyre $\left(314 \mathrm{~km}^{2}\right)$, Calder and Douglas $\left(231 \mathrm{~km}^{2}\right)$, the underlying geology is shale, grit and sandstone. Across the Ribble and Wyre basins, 26 sites were monitored to cover a wide range of catchment typologies and gradients. Figure 1 provides a map of the study area and the location of the sampling points. Details of the sites, grid references and average values for some basic chemical parameters may be found in Table 1.

For the Ribble basin, three sites were monitored on the upper (R4: Gisburn), mid (R5: Mitton) and lower reaches of the main stream (R7: Ribchester), with increasing urban/industrial inputs especially from the major tributary of the Calder that enters the Ribble between the middle and lower monitoring sites. Four tributaries were also monitored, the rural Hodder and the urban/industrial impacted Calder, Darwen and Douglas with 3, 5, 1 and 7 sites respectively. For the Calder and Douglas, a series of sites were studied ranging from the clean headwater areas through the urban/industrial centers within the valleys to the agricultural areas of the lowlands in the case of the Douglas. In terms of urban inputs and the industrial towns, the Calder is impacted by Colne, Burnley and Accrington, the Darwen by Darwen and Blackburn and the Douglas by Wigan and Skelmersdale. 
Figure 1. Location map of Calder, Douglas, Ribble and Wyre river basins and respective sampling sites.

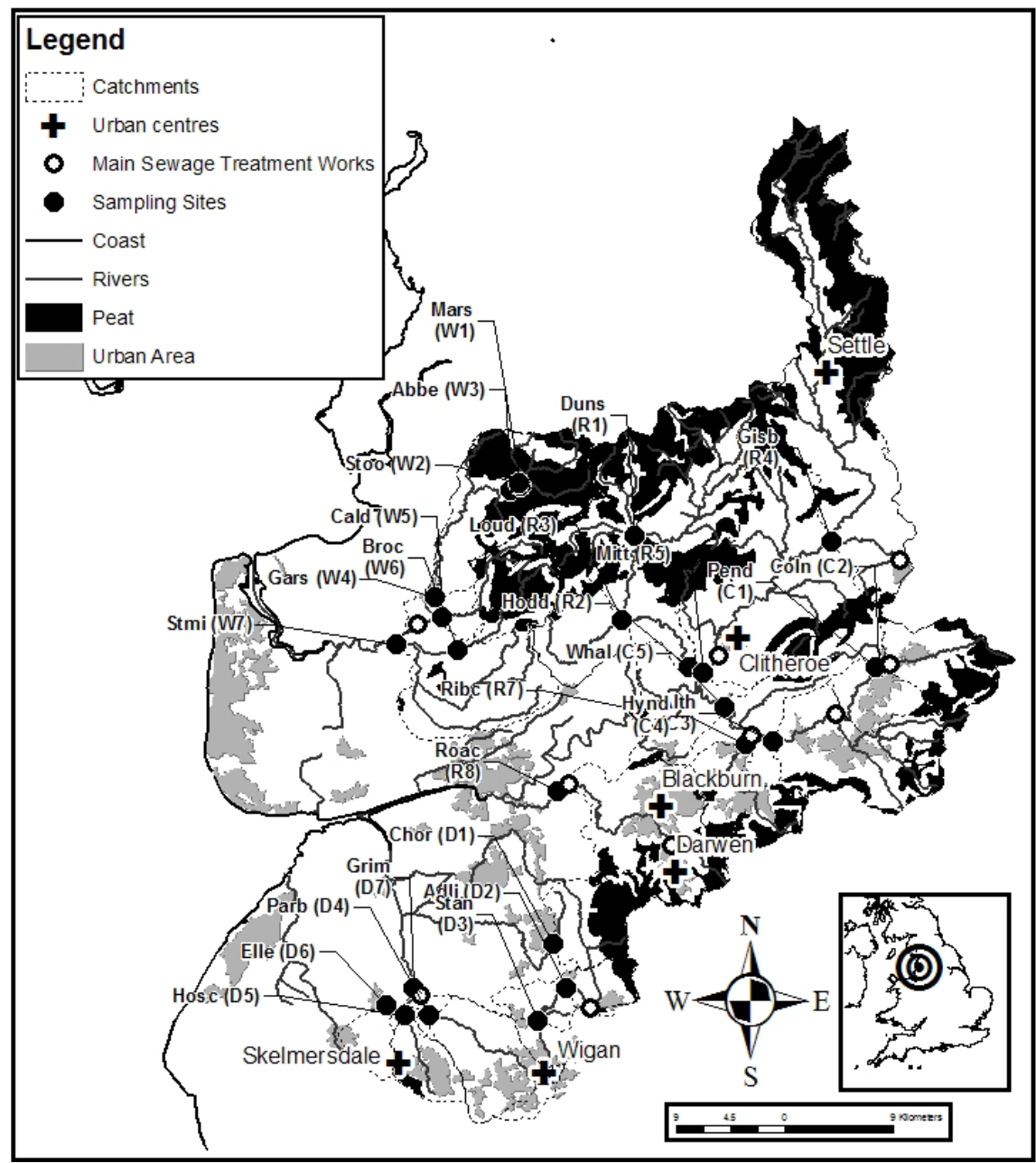

Table 1. Site names, locations, mean values $(n=42)$ for boron $(B)\left(\mu g L^{-1}\right)$, total suspended solids (TSS mg L ${ }^{-1}$ ) dissolved organic carbon (DOC $\mathrm{m} \mathrm{L} \mathrm{L}^{-1}$ ).

\begin{tabular}{lllcccc}
\hline River & No. & Site_name & O S Grid ref & Dissolved B & TSS & DOC \\
\hline River Calder basin & & & & & & \\
Pendle Water & C1 & Barrowford & SD859392 & 16.4 & 4.3 & 7.0 \\
Colne Water & C2 & Barrowford & SD862392 & 49.8 & 10.8 & 7.8 \\
Calder & C3 & Altham Bridge & SD774330 & 47.1 & 10.8 & 7.2 \\
Hyndburn Brook & C4 & Hyndburn & SD752328 & 67.2 & 13.2 & 7.4 \\
Calder & C5 & Whalley & SD733359 & 53.3 & 9.9 & 7.9 \\
\hline \multirow{2}{*}{ River Douglas basin } & & & & & & \\
Yarrow & & Chorley & SD591161 & 25.1 & 10.1 & 7.7 \\
Douglas & D1 & Adlington & SD602125 & 34.3 & 9.5 & 6.1 \\
Douglas & D2 & Standish & SD579100 & 43.4 & 10 & 7.3 \\
Douglas & D4 & Parbold & SD489103 & 84.1 & 11.4 & 7.0 \\
Tawd & D5 & Hoscar & SD469104 & 73.5 & 11.7 & 9.9 \\
Eller Brook & D6 & Briars Lane & SD454112 & 53.5 & 15.9 & 12.2 \\
Douglas & D7 & Wanes Blades Br. & SD476126 & 94.8 & 14.6 & 10.6 \\
\hline
\end{tabular}


Table 1. Cont.

\begin{tabular}{lllcccc}
\hline River & No. & Site_name & O S Grid ref & Dissolved B & TSS & DOC \\
\hline River Ribble basin & & & & & & \\
Dunsop & R1 & Dunsop & SD659501 & 8.7 & 2.9 & 5.2 \\
Loud & R2 & Mytham Bridge & SD649430 & 19.2 & 13.4 & 8.9 \\
Hodder & R3 & Lower Hodder & SD704392 & 12.4 & 4.3 & 7.5 \\
Ribble & R4 & Gisburn & SD822496 & 17.1 & 4.8 & 8.6 \\
Ribble & R5 & Great Mitton & SD716387 & 17.8 & 5.4 & 8.8 \\
Calder & R6 & Whalley & SD733359 & 53.3 & 9.9 & 7.9 \\
Ribble & R7 & Ribchester & SD662366 & 26.6 & 5.8 & 8.2 \\
Darwen & R8 & Roach Bridge & SD595288 & 71.3 & 11.4 & 10.4 \\
\hline \multirow{2}{*}{ River Wyre basin } & & & & & & \\
Marshaw Wyre & W1 & Marshaw Bridge & SD565542 & 9.1 & 4.2 & 7.5 \\
Tarnbrook Wyre & W2 & Stoops Bridge & SD562544 & 9.1 & 6.3 & 7.6 \\
Wyre & W3 & Abbeystead & SD555538 & 9.1 & 7.1 & 7.9 \\
Wyre & W4 & Garstang Bridge & SD495445 & 12.7 & 5.6 & 9.1 \\
Calder & W5 & Calderbridge & SD499433 & 15.5 & 5.7 & 9.0 \\
Brock & W6 & Bilsborough & SD511406 & 16.1 & 4.2 & 9.4 \\
Wyre & W7 & St Michaels & SD462411 & 18.3 & 8.7 & 10.3 \\
\hline
\end{tabular}

For the Wyre basin, an upland-lowland sequence was monitored with a total of seven sites: Two headwater inputs (the Marshaw W1 and Tarnbrook Wyre W2); the outfall from a shallow lake just below the confluence of the two tributaries (Abbeystead), two tributaries (the Calder W5 and Brock W6) that drain to the lower Wyre; two main-stem sites on the mid (Garstang) and lower reaches of the Wyre (St. Michaels W7). The site was also downstream of Garstang and St Michaels sewage treatment works and just upstream of the tidal influence. The lower tributaries, drain from the Trough of Bowland and have farming in the lowland areas; N.B. there are two rivers named "Calder", one is a main tributary feeding into the Ribble and the other is a small stream in the Wyre Basin.

The study covers the whole range of river systems from the clean headwaters of the Dunsop, Marshaw Wyre and Tarnbrook Wyre to the lower reaches close to the tidal limit for the Ribble at Ribchester, the Darwen at Roach Bridge, the Douglas at Wanes Blades Bridge and the Wyre at St. Michaels. The river chemistry of the headwater sites is characterized as containing background amounts of boron, suspended solids and DOC. NB Boron is an excellent indicator of sewage treatment works [5]. Conversely the lower reach sites are heavily impacted from point and diffuse sources that contribute to the greater concentrations of these parameters (Table 1). Other major physico-chemical variables have been measured and reported elsewhere [17].

\subsection{Sampling and Methodology}

All the sites were sampled fortnightly for the first 12 months, starting on 18 February 2008, and then once every four weeks thereafter. Sampling was conducted in a standardized manner to ensure that samples from each location were sampled at the same time at each location, and always between 08:00 and 14:00, to ensure that the effects of diurnal cycling for $\mathrm{Cd}$ and $\mathrm{Ni}$ are minimal. Data is 
summarized up to 31 March 2010. Water samples were collected from bridges using a weighted polypropylene sampler and water temperature was directly recorded at the time of sampling. Field notes were also taken, relating to weather conditions and water height. Separate samples were taken at each site for trace metals in a $500 \mathrm{~mL}$ acid-washed polyethylene bottle) and protected from contamination using resealing plastic bags. In the case of the trace metals, two samples were taken, one for dissolved (filtered and then acidified) and the other for total (unfiltered and acidified). The acid available particulate fraction- (AAP) is defined as the difference between the unfiltered sub-sample and the dissolved sub-sample. On return to the laboratory, all the samples were stored in the dark at around $4{ }^{\circ} \mathrm{C}$ to minimize sample degradation. For the metals analysis, sub-samples of filtered (using Whatman $0.45 \mu \mathrm{m}$ cellulose nitrate filters) and unfiltered water were acidified to $1 \%$ with concentrated nitric acid (Baker Ultrex 70\%) within one day of sampling and stored for a minimum time of overnight prior to analysis.

The concentrations of the trace metals $\mathrm{Ni}, \mathrm{Pb}$ and $\mathrm{Cd}$ were determined using a Perkin Elmer Elan DRC II Inductively Coupled Plasma-Mass Spectrometry (ICPMS). The acid available particulate fraction was calculated as the difference between the acid-leached total (i.e., the acidified unfiltered sub-sample) and the dissolved fraction (filtered and acidified sub-sample). This fraction is referred to here as the acid available particulate component (AAP), and it represents a more labile fraction. It excludes the more refractory and acid-unreactive components of the suspended sediments. Although, reference is also given to a dissolved fraction, for many transition metal components in particular, this fraction also comprises colloidal material that is not "truly" dissolved [18,19]. For the analysis, the instruments are optimized for low concentrations of trace metals and calibrated on the day of use using a range of standard solutions. An internal standard is used in calibrants and samples containing Ga, In and Re to compensate for instrumental drift. A four-point calibration is used to cover the range up to $10 \mu \mathrm{g} \mathrm{L}^{-1}$. Values exceeding the top calibration standard were diluted and the analysis repeated. Detection limits of the ICP-MS analytical method for the trace metals are $0.01 \mu \mathrm{g} \mathrm{L}^{-1}$ for $\mathrm{Ni}$, $0.002 \mu \mathrm{g} \mathrm{L}^{-1}$ for $\mathrm{Cd}$, and $0.06 \mu \mathrm{g} \mathrm{L}^{-1}$ for $\mathrm{Pb}$. Concentrations are presented without the limit of detection filter applied. Boron was determined by ICP-OES using a Perkin Elmer DV4300 model. Total suspended solids was determined gravimetrically using GF/C filters. The dissolved organic carbon method is empirically non-purgable organic carbon: initially the sample is acidified and purged to remove the inorganic fraction and the combusted and measured using a thermal conductivity detector (Shimadzu TOC-V $\mathrm{V}^{\mathrm{CPH}}$ instrument). The measurements were validated using values from the analysis of internal Quality Control samples, certified reference material (National Research Council Canada, Riverine Water: SLRS-5) and regular proficiency testing samples supplied by Aquacheck Ltd. The trace metal analysis is accredited by United Kingdom Accreditation Service to ISO 17025. The performance characteristics of the method for the $0.5 \mu \mathrm{g} \mathrm{L}{ }^{-1}$ QC samples $(\mathrm{n}=12$, analyzed in 6 batches on different days) are: for \% bias and coefficient of variation $\mathrm{Cd}-1,2.6$; $\mathrm{Ni} 0,2.3$ and $\mathrm{Pb} 5,9.1$.

Flow information is based on the Environment Agency gauging sites across the region. This information is used to estimate the low (base flow) and high (storm flow) averages using the 10 and $90 \%$ flow data and estimated from long-term hydrological statistics at relevant stations. In some cases there were no gauges for particular sites the values for the nearest flow gauge are used. Clearly, the flows for the different sites will differ due to catchment size and rainfall variations with altitude. 
However, high correlations of flow between sites are observed and the relative differences in estimating low and high flows are reasonable.

\subsection{Statistics, Spatial Analysis and Load Estimates}

Pearson correlation coefficients are used throughout. Spatial statistics of each catchment were generated based on the Land cover map 2000 Level II and III dataset, the Agcensus 2000 dataset, and the BGS DigMapGB-625 subsurface geology dataset. Data was analyzed at full catchment level, and also using a $50 \mathrm{~m}$ buffer along the river network to investigate riparian influences. Load estimates for all determinants were estimated from 15 minute resolution discharge data, using log-log concentration discharge rating curves and a correction factor to remove bias [20]. The estimates are based on the data from 2009. Metal transport loads to the Ribble estuary were calculated by summing the loads for the Ribble at Great Mitton (R5), the Darwen at Roach Bridge (R8) and the Douglas at Grimshaw Green (D7). Loads for the Wyre estuary are from the data at St Michaels (W7). The method for calculating the flow weighted mean concentrations is using a regression method [21].

\subsection{Supplementary Information}

As the datasets are significant in size, only a summary table of the values for each river system is provided within the paper. The full summary statistics tables for the dissolved metal concentrations for each of the 26 sites are provided as spreadsheets in an Excel workbook for supplementary information.

\section{Results}

Streams and rivers in the Ribble and Wyre catchments all contain relatively low concentrations of dissolved $\mathrm{Ni}$ [D-Ni], dissolved $\mathrm{Cd}$ [D-Cd] and dissolved $\mathrm{Pb}$ [D-Pb] (Table 2) but well above and 3 to 150 times the detection limit of the ICP-MS analytical method. Average [D-Ni] is $1.5 \mu \mathrm{g} \mathrm{L}^{-1}$ with a range from $0.89 \mu \mathrm{g} \mathrm{L}^{-1}$ in the headwater site of the Dunsop to $2.76 \mu \mathrm{g} \mathrm{L}^{-1}$ for the Hyndburn Brook from the industrial area of Accrington. For [D-Cd] the average is $0.030 \mu \mathrm{g} \mathrm{L}^{-1}$, with the lowest concentration occurring at two sites on the Douglas $\left(0.018 \mu \mathrm{g} \mathrm{L}^{-1}\right)$ and the highest for Hyndburn Brook $\left(0.062 \mu \mathrm{g} \mathrm{L}^{-1}\right)$. For [D-Pb] the average is $0.39 \mu \mathrm{g} \mathrm{L}^{-1}$ with the lowest concentration at the clean site of Pendle Water at Barrowford and higher for the agricultural Loud possibly due to the addition of agricultural amendments. For [D-Ni], amounts increase as the river proceeds from its headwaters down towards the Ribble and Wyre estuaries, whilst [D-Pb] and [D-Cd] show consistent values throughout the catchment. A significant amount of $\mathrm{Cd}\left(0.016 \mu \mathrm{g} \mathrm{\textrm {L } ^ { - 1 }} ; 34 \%\right.$ of the total $)$ and $\mathrm{Pb}$ $\left(0.65 \mu \mathrm{g} \mathrm{L}^{-1} ; 55 \%\right)$ is in the AAP form $(>0.45 \mu \mathrm{m})$, whilst Ni occurs predominantly in the dissolved form (92\%). The highest AAP concentrations occur for Hyndburn Brook (for $\mathrm{Cd}$ and $\mathrm{Pb}$ ), the Loud $(\mathrm{Cd})$, the Douglas sites $(\mathrm{Pb})$ and Tarnbrook Wyre $(\mathrm{Ni})$.

Regional inputs of these three metals appear to arise mostly from diffuse sources as the storm-flow (HF) concentrations are generally greater than at base-flow (LF) condition. The exceptions are for $\mathrm{Ni}$ on the Calder and Ribble. For [D-Pb] the flow weighted mean (FWM) decreases from the Marshaw and Tarnbrook Wyre tributaries $\left(0.72 \mu \mathrm{g} \mathrm{L}^{-1}\right.$ and $0.66 \mu \mathrm{g} \mathrm{L}^{-1}$ respectively) down to $0.58 \mu \mathrm{g} \mathrm{L}^{-1}$ for St. Michaels. Even though the monitoring is limited to two years, it is possible to observe annual and 
seasonal cycling. For example, there is annual cycling of $\mathrm{D}-\mathrm{Cd}$ and $\mathrm{D}-\mathrm{Pb}$ for the streams and rivers that gives maxima during the months July through to December when the river flow is greater (Figure 2d) for both metals except for Hyndburn Brook, and the Douglas for D-Cd (Figures 2b-2c). For D-Ni, the seasonal difference is present for the Wyre catchment, and Pendle Water, the Yarrow, Dunsop and the Hodder (Figure 2a). Across all the sites there is a significant relationship between the dissolved metals D-Cd and D-Pb and the river flow (Figures $3 \mathrm{a}-3 \mathrm{c}$ ), and for D-Cd and D-Pb high flow concentrations exceed low flow concentrations. For the four clean water sites of Marshaw Wyre (W1), Tarnbrook Wyre (W2), Dunsop (R1) and Pendle Water (C1), the dissolved trace metals strongly correlate with each other. [D-Ni] and [D-Cd] are strongly related to DOC and flow (FQ), but not with [D-B]. Dissolved $\mathrm{Pb}$ exhibits different behaviour across the four sites: for Pendle Water and Tarnbrook Wyre, [D-Pb] correlates positively with $\mathrm{B}$ and negatively with flow, whilst for the Dunsop and Marshaw Wyre [D-Pb] relates to DOC and positively with flow.

Table 2. Summary data $(\mathrm{n}=42)$ for dissolved $\mathrm{Ni}, \mathrm{Cd}$ and $\mathrm{Pb}$ for each river catchment $\left(\mu \mathrm{g} \mathrm{L}^{-1}\right)$.

\begin{tabular}{|c|c|c|c|c|c|c|c|c|c|c|}
\hline River & Min & $\operatorname{Max}$ & Mean & Median & FWM & $\mathbf{L F}$ & HF & $\mathbf{a}$ & $\mathbf{b}$ & AAP \\
\hline \multicolumn{11}{|l|}{ Nickel } \\
\hline Calder & 0.34 & 6.12 & 2.03 & 1.91 & 2.01 & 2.69 & 1.82 & 1.98 & 2.08 & 0.17 \\
\hline Douglas & 0.22 & 4.65 & 1.52 & 1.51 & 1.55 & 1.54 & 1.70 & 1.56 & 1.48 & 0.18 \\
\hline Ribble & 0.00 & 6.28 & 1.45 & 1.34 & 1.48 & 1.68 & 1.47 & 1.42 & 1.50 & 0.12 \\
\hline Wyre & 0.22 & 6.34 & 1.40 & 1.31 & 1.58 & 0.86 & 1.57 & 1.12 & 1.73 & 0.41 \\
\hline \multicolumn{11}{|c|}{ Cadmium } \\
\hline Calder & 0.009 & 0.151 & 0.036 & 0.033 & 0.044 & 0.027 & 0.051 & 0.034 & 0.040 & 0.023 \\
\hline Douglas & 0.004 & 0.254 & 0.021 & 0.018 & 0.023 & 0.017 & 0.028 & 0.022 & 0.020 & 0.018 \\
\hline Ribble & 0.008 & 0.209 & 0.035 & 0.031 & 0.044 & 0.028 & 0.053 & 0.032 & 0.040 & 0.017 \\
\hline Wyre & 0.005 & 0.128 & 0.029 & 0.027 & 0.038 & 0.017 & 0.047 & 0.022 & 0.038 & 0.008 \\
\hline \multicolumn{11}{|l|}{ Lead } \\
\hline Calder & 0.02 & 1.75 & 0.28 & 0.17 & 0.43 & 0.15 & 0.70 & 0.29 & 0.40 & 0.62 \\
\hline Douglas & 0.04 & 3.81 & 0.48 & 0.40 & 0.58 & 0.34 & 0.82 & 0.36 & 0.53 & 1.25 \\
\hline Ribble & 0.03 & 1.88 & 0.35 & 0.24 & 0.53 & 0.14 & 0.73 & 0.25 & 0.48 & 0.38 \\
\hline Wyre & 0.03 & 1.37 & 0.42 & 0.33 & 0.58 & 0.27 & 0.79 & 0.27 & 0.58 & 0.24 \\
\hline & & & $\begin{array}{l}\mathrm{LF}- \\
\mathrm{HF}- \\
\mathrm{FWl} \\
\mathrm{AAI} \\
\mathrm{a}- \\
\mathrm{b}-\end{array}$ & $\begin{array}{l}\text { low flow } \\
\text { ligh flow } \\
\text { I-flow } \\
\text {-acid av } \\
\text { n-Jun me } \\
\text { l-Dec m }\end{array}$ & $\begin{array}{l}\text { lean }(10 \\
\text { lean }(90 \\
\text { ighted } \mathrm{n} \\
\text { lable par } \\
\mathrm{n} \text {; } \\
\text { n. }\end{array}$ & $\begin{array}{l}\text { ercentil } \\
\text { ercentile } \\
\text { ean; } \\
\text { iculate f }\end{array}$ & ction m & & & \\
\hline
\end{tabular}


Figure 2. Monthly trends in toxic metals concentrations (a) $\mathrm{Ni}$ (b) $\mathrm{Cd}$ (c) $\mathrm{Pb}$ and (d) discharge for clean sites of the Dunsop (R1), Marshaw Wyre (W1), Pendle Water (C1) and Tarnbrook Wyre (W2).

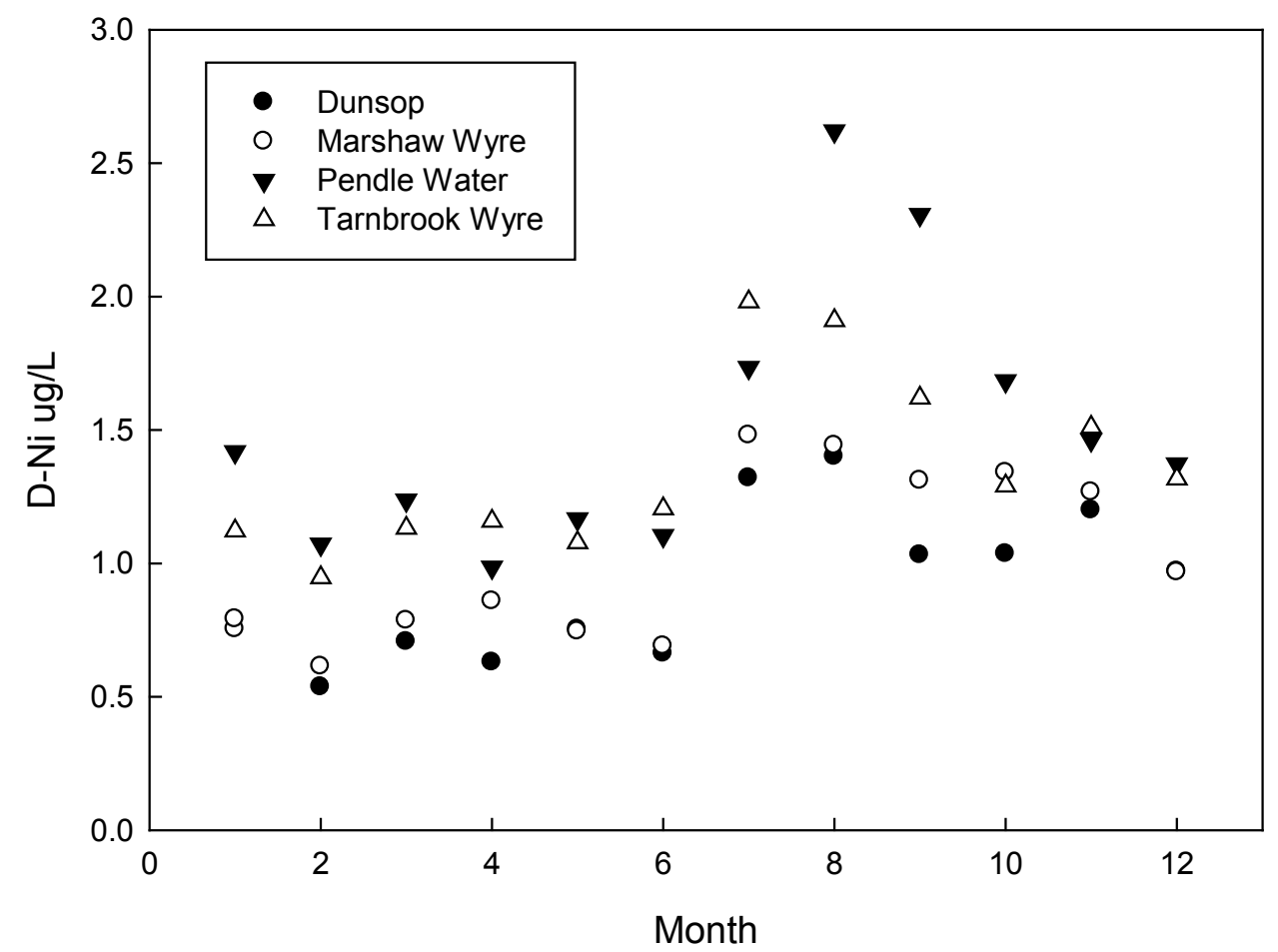

(a) Nickel

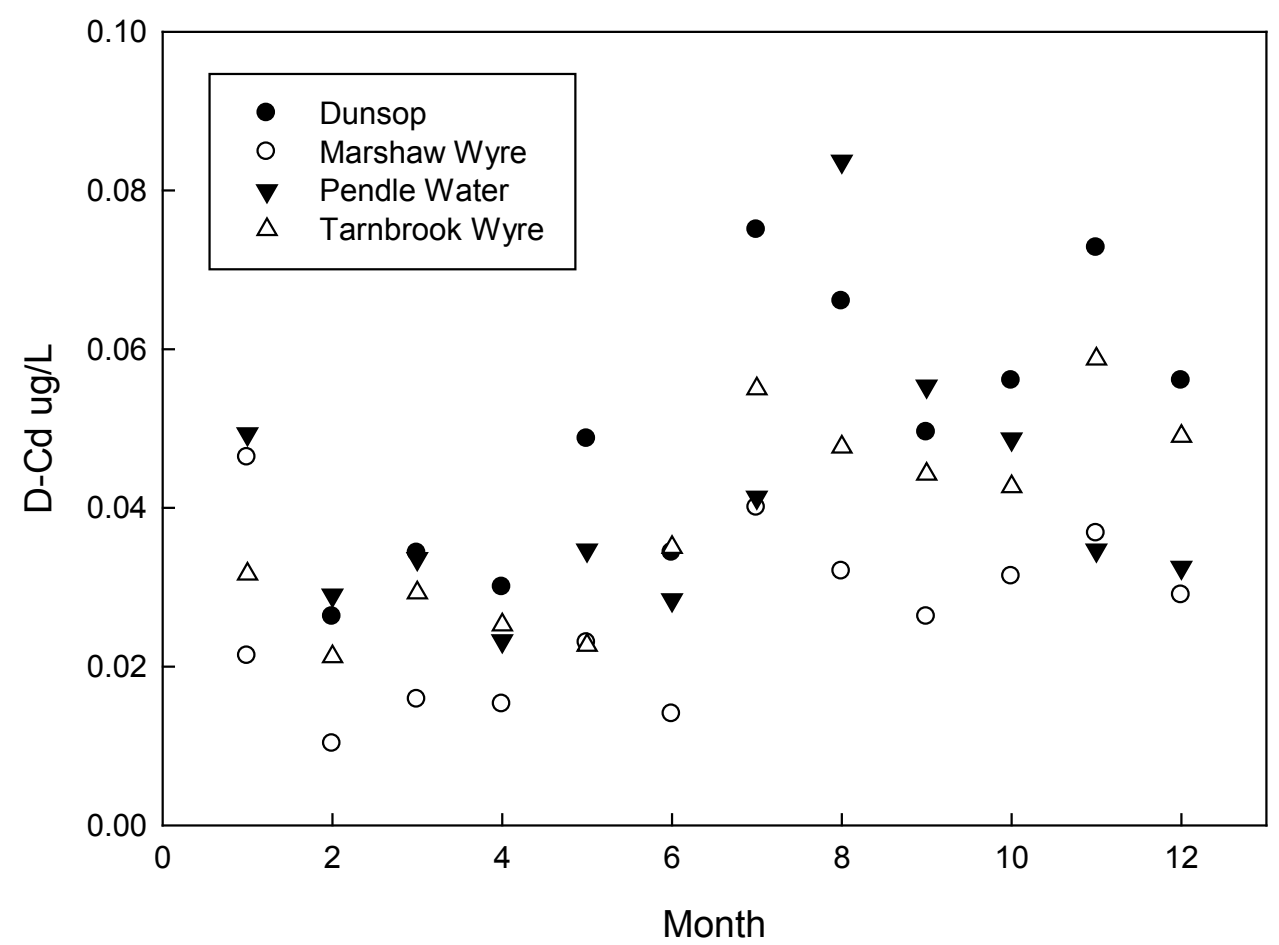

(b) Cadmium 
Figure 2. Cont.

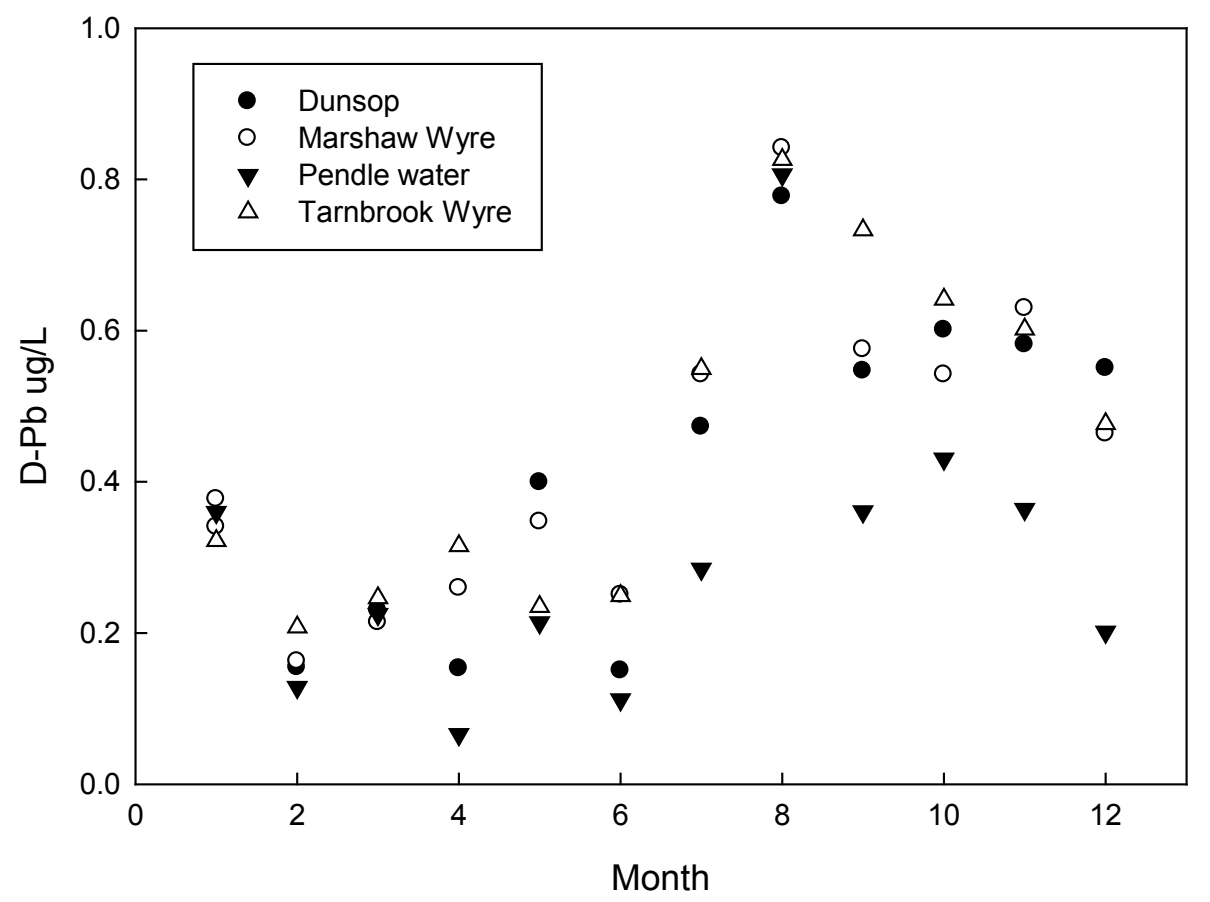

(c) Lead

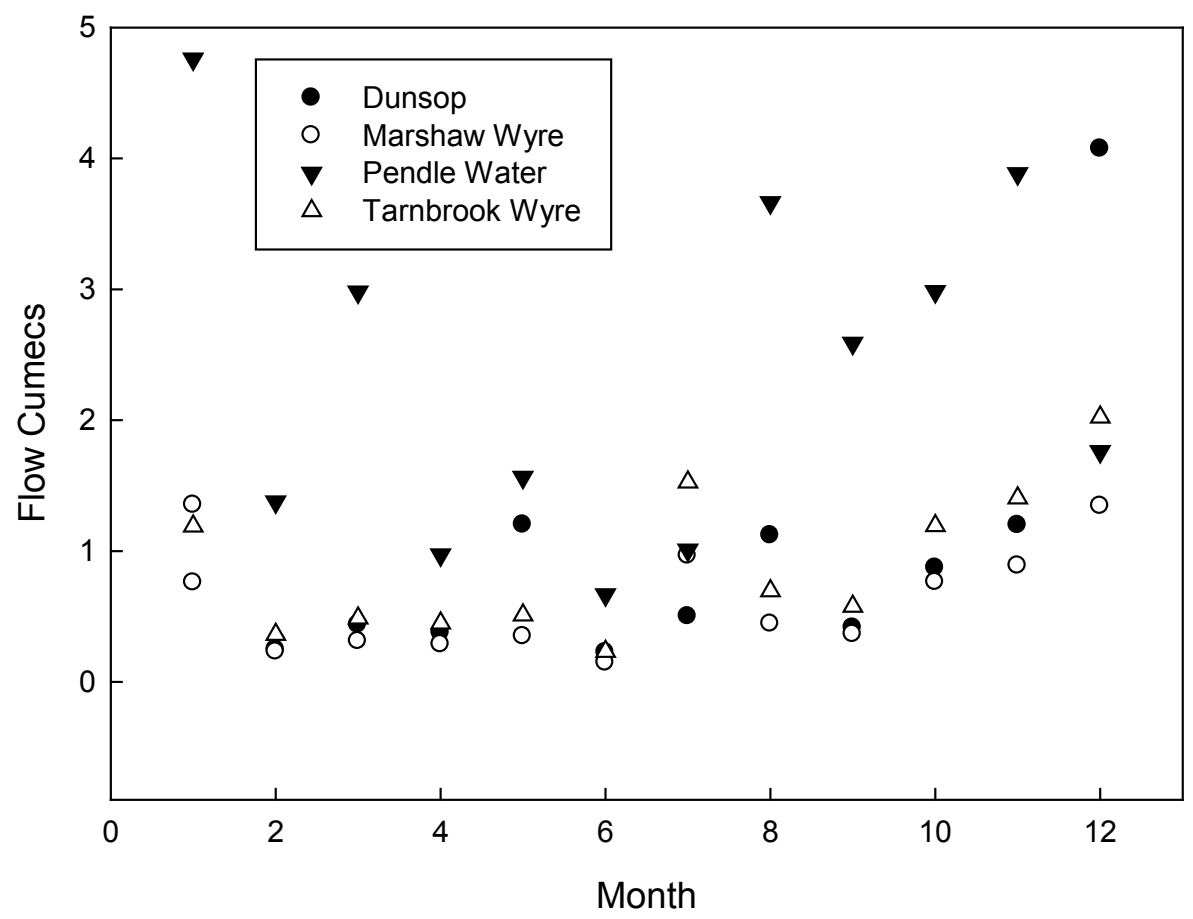

(d) Flow (FQ)

For the four most impacted sites of the Douglas at Grimshaw Green, Darwen, Hyndburn Brook and Calder at Whalley with the highest [D-B] (Table 1), the trace metals do not correlate with each other and there are no strong relationships for the metals across the sites (Table 3). The three metals [D-Ni], [D-Cd] and [D-Pb] are generally not related to $\mathrm{B}, \mathrm{DOC}, \mathrm{pH}$ or flow, with some exceptions. In particular Hyndburn Brook [D-Pb] is related positively to DOC and flow and negatively to [D-B] and $\mathrm{pH}$. 
The Ribble and Wyre and associated tributaries are mainly fed by surface run-off from the surrounding hills producing a flashy character to the flows [16]. Estimates of annual metals fluxes to estuaries range from 6 ton $\mathrm{y}^{-1}$ for AAP-Cd in the Wyre up to 550 ton $\mathrm{y}^{-1}$ for D-Ni in the Ribble (Table 4). The discharges to both estuaries are similar orders of magnitude, and similar for the amounts of dissolved and particulate fractions.

Table 3. Correlation coefficients for selected sites for (a) D-Ni; (b) D-Cd; and (c) D-Pb $(\mathrm{n}-1=42 ; \mathrm{p}<0.001$ in bold $)$.

\begin{tabular}{lcccccc}
\hline Site & Diss-B & DOC & pH & FQ & D-Cd & D-Pb \\
\hline Diss-Ni & & & & & & \\
Dunsop (R1) & -0.217 & $\mathbf{0 . 8 6 3}$ & $-\mathbf{0 . 6 8 7}$ & 0.303 & $\mathbf{0 . 9 3 1}$ & $\mathbf{0 . 8 8 0}$ \\
Marshaw Wyre (W1) & -0.184 & 0.914 & -0.642 & 0.397 & 0.860 & 0.855 \\
\hline Pendle Water (C1) & -0.021 & $\mathbf{0 . 7 8 2}$ & $-\mathbf{0 . 4 7 1}$ & $\mathbf{0 . 5 3 1}$ & $\mathbf{0 . 8 8 2}$ & $\mathbf{0 . 8 7 7}$ \\
Tarnbrook Wyre (W2) & -0.094 & $\mathbf{0 . 7 9 9}$ & $-\mathbf{0 . 5 4 9}$ & 0.230 & $\mathbf{0 . 7 2 4}$ & $\mathbf{0 . 8 1 2}$ \\
\hline Douglas @ Waynes (D7) & 0.295 & $\mathbf{0 . 3 2 3}$ & $-\mathbf{0 . 0 9 3}$ & -0.087 & 0.272 & -0.068 \\
Darwen (R8) & $\mathbf{0 . 6 0 6}$ & 0.154 & -0.198 & -0.428 & 0.273 & -0.026 \\
Hyndburn Brook (C4) & $-\mathbf{0 . 5 3 9}$ & 0.434 & $-\mathbf{0 . 5 1 9}$ & $\mathbf{0 . 6 3 7}$ & 0.276 & $\mathbf{0 . 6 7 9}$ \\
Calder @ Whalley (C5) & $\mathbf{0 . 6 6 6}$ & -0.158 & 0.304 & -0.293 & -0.115 & -0.022 \\
\hline Diss-Cd & & & & & D-Ni & D-Pb \\
\hline Dunsop (R1) & 0.296 & 0.018 & 0.317 & -0.224 & $\mathbf{0 . 9 3 1}$ & $\mathbf{0 . 8 4 2}$ \\
\hline Marshaw Wyre (W1) & -0.334 & $\mathbf{0 . 8 4 6}$ & $-\mathbf{0 . 8 3 8}$ & $\mathbf{0 . 6 7 2}$ & $\mathbf{0 . 8 6 0}$ & $\mathbf{0 . 8 8 3}$ \\
Pendle Water (C1) & -0.208 & $\mathbf{0 . 7 8 6}$ & $\mathbf{0 . 4 8 3}$ & $\mathbf{0 . 7 0 3}$ & $\mathbf{0 . 8 8 2}$ & $\mathbf{0 . 9 4 0}$ \\
Tarnbrook Wyre (W2) & -0.390 & $\mathbf{0 . 7 2 4}$ & $-\mathbf{0 . 8 4 8}$ & $\mathbf{0 . 6 2 0}$ & $\mathbf{0 . 7 2 4}$ & $\mathbf{0 . 7 3 6}$ \\
\hline Douglas @ Waynes (D7) & -0.300 & $\mathbf{0 . 5 0 0}$ & -0.283 & 0.302 & 0.272 & 0.250 \\
\hline Darwen (R8) & -0.014 & 0.187 & -0.176 & -0.044 & 0.273 & $\mathbf{0 . 5 5 4}$ \\
\hline Hyndburn Brook (C4) & 0.214 & 0.110 & -0.285 & 0.243 & 0.276 & 0.235 \\
\hline Calder @ Whalley (C5) & -0.294 & 0.161 & -0.126 & 0.348 & -0.115 & $\mathbf{0 . 4 7 7}$ \\
\hline Diss-Pb & & & & & D-Ni & D-Pb \\
\hline Dunsop (R1) & -0.314 & $\mathbf{0 . 9 1 5}$ & $-\mathbf{0 . 7 5 7}$ & $\mathbf{0 . 4 7 9}$ & $\mathbf{0 . 8 8 0}$ & $\mathbf{0 . 8 4 2}$ \\
\hline Marshaw Wyre (W1) & $\mathbf{0 . 6 8 3}$ & -0.458 & $\mathbf{0 . 6 9 6}$ & $-\mathbf{0 . 5 6 0}$ & $\mathbf{0 . 8 5 5}$ & $\mathbf{0 . 8 8 3}$ \\
\hline Pendle Water (C1) & $\mathbf{0 . 6 3 4}$ & -0.288 & 0.255 & $-\mathbf{0 . 6 1 4}$ & $\mathbf{0 . 8 7 7}$ & $\mathbf{0 . 9 4 0}$ \\
\hline Tarnbrook Wyre (W2) & -0.213 & $\mathbf{0 . 9 2 6}$ & $-\mathbf{0 . 6 4 4}$ & 0.375 & $\mathbf{0 . 8 1 2}$ & $\mathbf{0 . 7 3 6}$ \\
\hline Douglas @ Waynes (D7) & -0.179 & -0.146 & -0.342 & $\mathbf{0 . 7 4 8}$ & -0.068 & 0.250 \\
\hline Darwen (R8) & -0.446 & 0.026 & -0.208 & 0.435 & -0.026 & $\mathbf{0 . 5 5 4}$ \\
\hline Hyndburn Brook (C4) & $-\mathbf{0 . 5 6 7}$ & $\mathbf{0 . 4 7 5}$ & $-\mathbf{0 . 5 2 9}$ & $\mathbf{0 . 7 0 9}$ & $\mathbf{0 . 6 7 9}$ & 0.235 \\
\hline Calder @ Whalley (C5) & -0.470 & 0.239 & -0.365 & 0.716 & -0.022 & $\mathbf{0 . 4 7 7}$ \\
\hline & & & & & & \\
\hline
\end{tabular}

Table 4. Load estimates of dissolved metals discharged into the Ribble and Wyre estuaries $\left(\mathrm{t}^{-1}\right)$.

\begin{tabular}{lcc}
\hline & Ribble estuary & Wyre estuary \\
\hline D-Ni & 550 & 420 \\
D-Cd & 16 & 9 \\
D-Pb & 240 & 205 \\
AAP-Ni & 120 & 93 \\
AAP-Cd & 12 & 6 \\
AAP-Pb & 450 & 120 \\
\hline
\end{tabular}




\section{Discussion}

\subsection{Quality Status of Trace Metals in North West England Rivers}

The Water Framework Directive is a critical driver to evaluate risks and impacts on the inland and surface waters. The Environmental Quality Standard (EQS) annual average values assigned to the dissolved fraction of the three trace metal priority substances are $20 \mu \mathrm{g} \mathrm{L}^{-1}$ for [D-Ni] , $7.2 \mu \mathrm{g} \mathrm{L}^{-1}$ for [D-Pb] and a range of $0.08-0.25 \mu \mathrm{g} \mathrm{L}^{-1}$ for [D-Cd] depending on the hardness of the water specified in five class categories [2]. Concentrations of the dissolved metals for the Ribble, Wyre, Calder and Douglas catchments are at trace levels and well below the annual average EQS values for all three of these substances. For [D-Ni], [D-Cd] and [D-Pb] the regional averages of $1.5 \mu \mathrm{g} \mathrm{L}^{-1}, 0.030 \mu \mathrm{g} \mathrm{L}^{-1}$, and $0.39 \mu \mathrm{g} \mathrm{L}^{-1}$ respectively represent only a small fraction over the EQS values indicating that adequate remediation or control measures are in place to reduce the impacts of these trace metals on the surface waters in NW England. The maximum allowable concentration (MAC) for the three metals is defined as $20 \mu \mathrm{g} \mathrm{L}^{-1}$ for [D-Ni]; $7.2 \mu \mathrm{g} \mathrm{L}^{-1}$ for [D-Pb] and $0.45-1.5 \mu \mathrm{g} \mathrm{L} \mathrm{L}^{-1}$ for [D-Cd] depending on the hardness of the water; ie the values are the same as the annual average values except for $\mathrm{Cd}$. For the 2-year period of this monitoring program, there are no occasions when values for these dissolved metals exceeding the EQS MAC guideline values.

Contemporary data for the trace metals in the rivers of North West England is scarce, excepting for a recent study that reported values for $\mathrm{Pb}$ on unfiltered samples for the period 1995 to 2001 [7]. Concentrations for high to intermediate impacted sites associated with urban and industrial areas were considerably higher (total $\mathrm{Pb}$ (AAP + dissolved): 30-345 $\mu \mathrm{g} \mathrm{L}^{-1}$ ) than in the current study and exceeding the EQS levels for dissolved $\mathrm{Pb}$ [7]. For the impacted sites of Hyndburn Brook, the Calder at Whalley, the Douglas at Grimshaw Green and the Ribble at Ribchester, we find significantly lower average total $\mathrm{Pb}\left(0.5-1.6 \mu \mathrm{g} \mathrm{L}^{-1}\right)$. In a wider context, from the 1990's, trace metals averages for the major rivers in Eastern England (from the LOIS project data) discharging into the Humber estuary [13,22] were significantly higher (3-4 times greater) than for the Ribble / Wyre catchments values from this study. It is important to point out the predominant sources of metals in most of these Eastern rivers catchments are likely to be mining derived [23] whereas the Ribble lies on the margin of the orefield and is less-affected. Nevertheless the annual averages for the Humber region were still below the current EQS annual average limits, although there were occasional high values that exceeded the MAC. Similarly from the same region [24], total $\mathrm{Ni}$ were generally $<11 \mu \mathrm{g} \mathrm{L}^{-1}$, except for the Tame (a tributary of the River Trent) with concentrations exceeding $100 \mu \mathrm{g} \mathrm{L}^{-1}$. On the basis of the above evidence, it is not possible to conclude categorically whether the current data reflects significant improvements in the control of trace metals inputs to UK rivers over the past decade, or simply good quality status for dissolved trace metals in the rivers of the region of NW England. 
Figure 3. The relationships of concentration with flow for the dissolved metals (a) $\mathrm{Ni}$, (b) $\mathrm{Cd}$, and (c) $\mathrm{Pb}$.

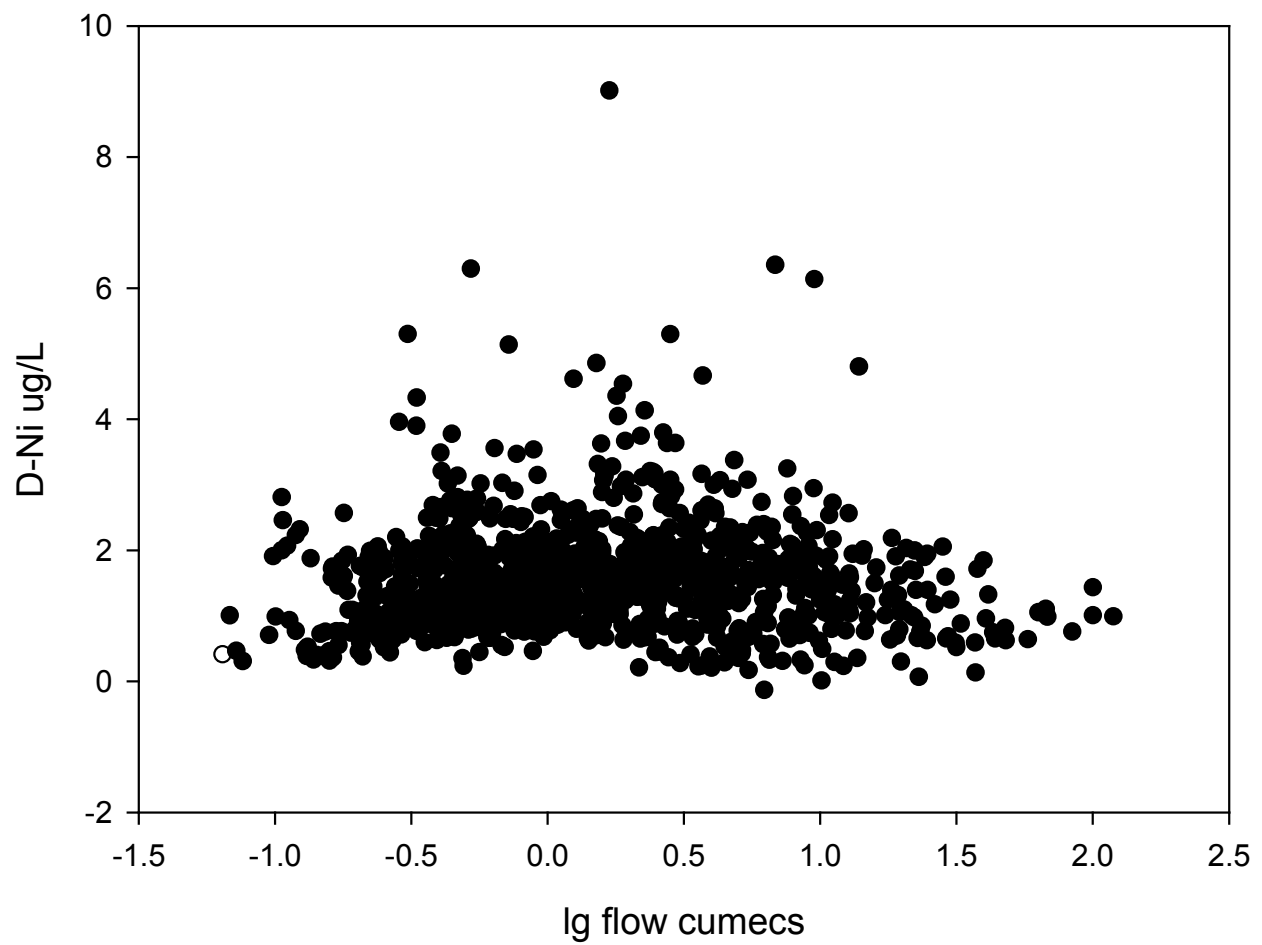

(a) $\mathrm{Ni}\left(\mathrm{r}^{2}=0.0015 ; \mathrm{p}=0.0973\right.$

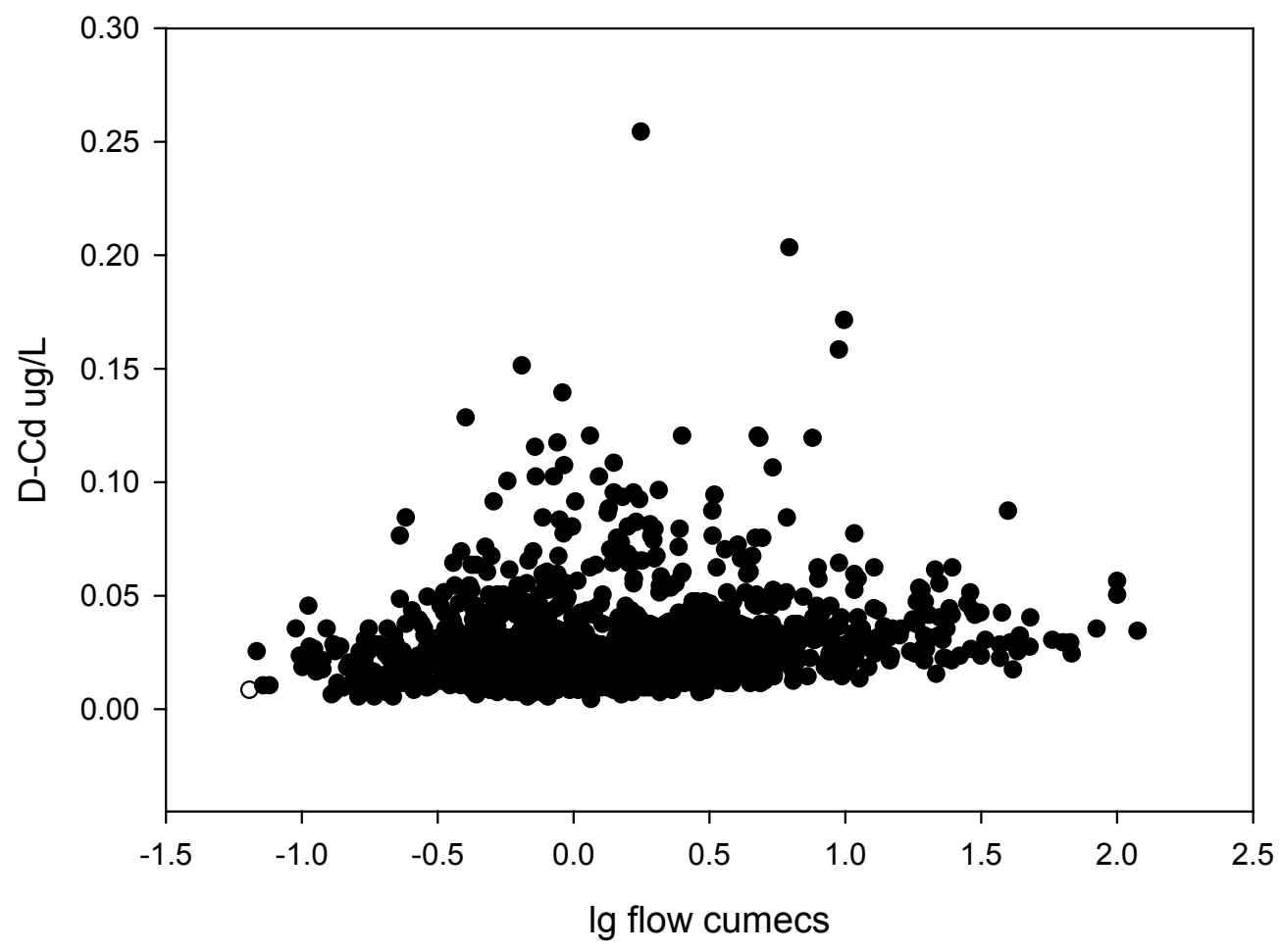

(b) $\mathrm{Cd}\left(\mathrm{r}^{2}=0.081 ; \mathrm{p}<0.0001\right)$ 
Figure 3. Cont.

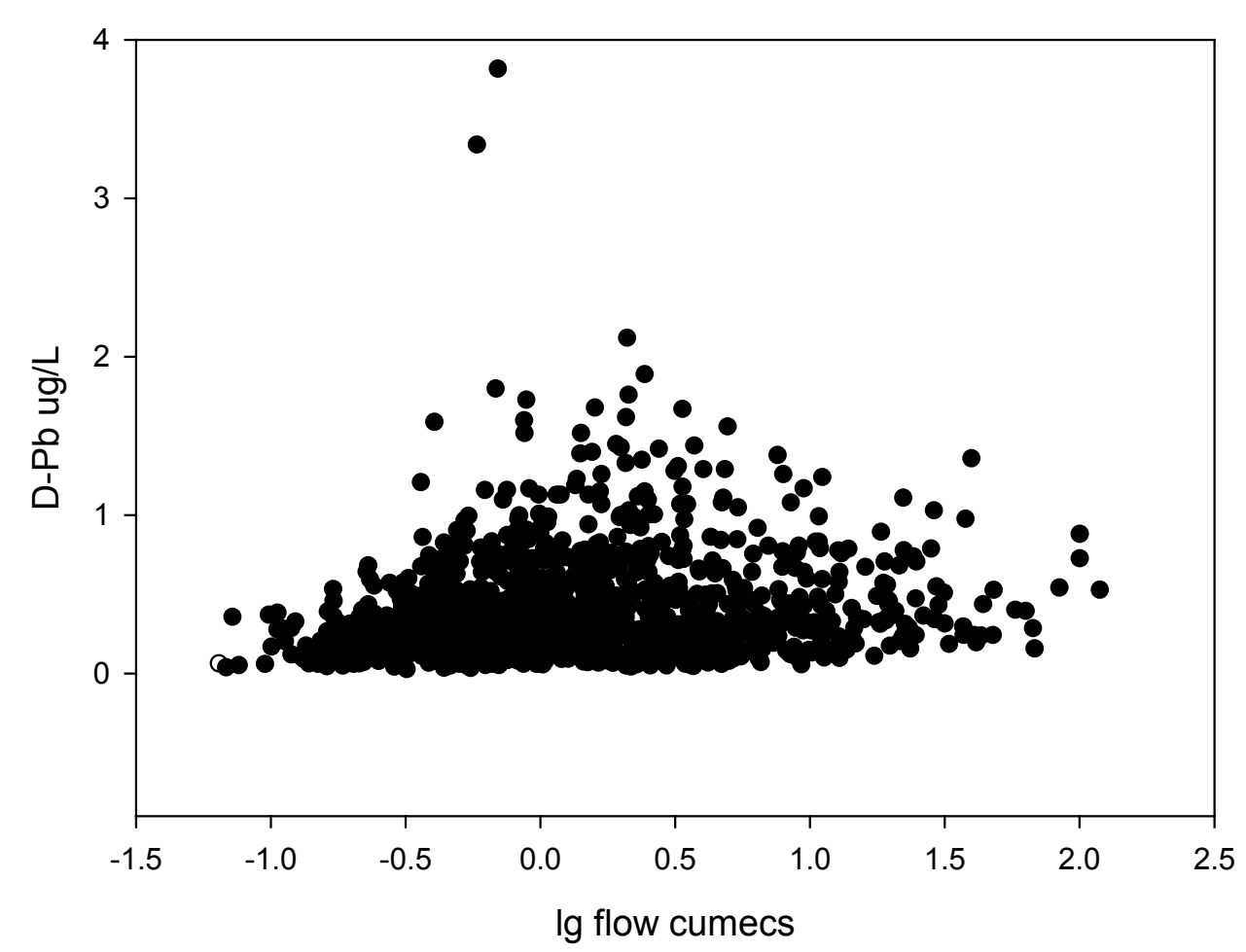

(c) $\mathrm{Pb}\left(\mathrm{r}^{2}=0.0187 ; \mathrm{p}<0.0001\right)$

\subsection{Pollution Inputs to Rivers}

Inputs to streams and rivers occur from atmospheric deposition, point sources such as sewage treatment works (STWs) or industrial effluent, or from diffuse pollution from agriculture use, fertilizers and sewage sludge application [25]. The large decline in emissions of $89 \%$ for $\mathrm{Ni}, 92 \%$ for $\mathrm{Cd}$ and $99 \%$ for $\mathrm{Pb}$ since 1970 [10] is likely to have contributed significantly by the reduction in their concentrations in headwater streams. The trace metals $\mathrm{Ni}, \mathrm{Cd}$ and $\mathrm{Pb}$ bind strongly to soil organic matter and the complexes transport with DOC [26-28]. For Ni, there is evidence to suggest that it migrates through the system almost un-retarded [26]. Elevated storm-flow concentrations of $\mathrm{Pb}$ arise from leaching of the uplands peat stores into streams and controlled by DOC availability [27]. The pattern we observe of higher autumn / winter concentrations is likely to relate to the high rainfall for this period and others have also noted the phenomenon of higher winter concentrations for $\mathrm{Pb}[7,13]$. For the headwater sites of the Dunsop (R1), Tarnbrook Wyre (W2), Marshaw Wyre (W1) and Pendle Water $(\mathrm{C} 1)$, generally [D-Ni], [D-Cd] and [D-Pb] correlate with stream flow (FQ) indicating a strong link to atmospheric deposition and transport through the system as DOC complexes (Table 3). Entrainment of metal-rich sediment from mining operations (e.g., instream deposits/spoil heap runoff) could also contribute to the pattern of increasing high flow concentrations of metals. There are exceptions for Marshaw Wyre and Pendle Water for [D-Pb]; for these 2 streams [D-Pb] correlate strongly to [D-B], a marker for point source inputs from public or private sewage treatment plants [29], and negatively with DOC, pointing to the possibility that there is point source inputs from septic tanks discharging $[\mathrm{D}-\mathrm{Pb}]$ in these catchments. 
In contrast, for the valley and lowland areas, there are the direct human pressures associated with point source inputs for example from effluent from sewage treatment works. The four sites of the Douglas at Waynes Blades Bridge (D7), Darwen (R8), Hyndburn Brook (C4) and the Calder at Whalley (C5) are subject to significant point source discharges as indicated by the elevated [B] (Table 1) from STWs and industrial discharges. For [D-Cd] and [D-Pb] it appears that the STWs are not discharging elevated levels as values are no higher than for the upstream sites, and there is no correlation of these elements with [D-B] (Table 3). In contrast for [D-Ni] values are higher at the impacted sites (Table 2) and there is a significant correlation with [D-B]. This data supports the theory that the $\mathrm{Cd}$ and $\mathrm{Pb}$ entering the sewage treatment works has a strong tendency to stick to the solid particles [8], and therefore may be discharged to the environment as diffuse pollution arising from sewage sludge application to agricultural land. For [D-Ni] there are elevated concentrations downstream of the STWs on the Darwen and Calder at Whalley, together with strong positive correlations with [D-B]. Hyndburn Brook is an industrial tributary of the Calder down-stream of Accrington. This stream is atypical compared to other sites as the main drainage seems to come from underground sources with drainage through the impacted Accrington conurbation with evidence of industrial discharges of arsenic into the river [30].

For the extensive agricultural landscape of the Wyre the cycling of the trace metals relates mainly to diffuse inputs. Although there is no relationship of stream flow with trace metal concentrations, for $[\mathrm{D}-\mathrm{Cd}]$ and $[\mathrm{D}-\mathrm{Pb}]$ high flow concentrations are respectively two and three times the low flow concentrations. There is a similar two fold high flow enhancement for [D-Ni] in the Wyre. However, concentrations remain low and of little environmental consequence. Similar patterns for base and storms flow concentrations were reported for the Humber catchments [13]. For [D-Ni] the combination of the inputs from atmospheric, diffuse and point source inputs presents itself as an unclear pattern across the catchments.

From a UK perspective, there are specific examples of contamination from point sources attributed to STWs and historic legacy from coal mining and metallurgical industry [24], and other examples of major pollution events from abandoned mines [14,15]. For example, the majority of EQS failures for $\mathrm{Cd}$ are in the historic mining regions of the Yorkshire Pennines, South West England [11,12], Northumbria and West Wales [8]. River Basin Management Plans (RBMP) of most of Europe's river basins have now been submitted to the European Commission in Brussels and are at their early stage of implementation [3].

\section{Conclusions}

The current study presents a picture of low [D-Ni], [D-Cd] and [D-Pb], which may be attributable to a lower contribution from the atmosphere due to the use of lead-free petrol and the reduction in the combustion of coal for energy generation, good control discharges from sewage treatment plants, and small amounts migrating into the river from agricultural systems. These reliable estimates of annual averages and maximum values demonstrate that for these three priority substances identified for the Water Framework Directive, the rivers are of good quality with regard to chemical status. Dissolved cadmium and lead exhibit similar behavior to each other, whilst dissolved $\mathrm{Ni}$ is more mobile and retained less in the upland peat and the sewage treatment plants. Good quality analytical data is 
required for the further development of RBMPs and to facilitate the achievements of good environmental status in surface water bodies.

\section{References and Notes}

1. Cruz, J.V.; Pacheco, D.; Coutinho, R.; Cymbron, R.; Mendes, S.; Antunes, P.; Fonteila, J.; Freire, P. Chemical monitoring of river water bodies in an EU outmost region: examples from the Azores archipelago (Portugal). J. Environ. Monit. 2010, 12, 2216-2225.

2. The European Parliament and the Council of the European Union. EU Directive 2008/105/EC of the European Parliament and of the Council of 16 December 2008 on environmental quality standards in the field of water policy, amending and subsequently repealing Council Directives 82/176/EEC, 83/513/EEC, 84/156/EEC, 84/491/EEC, 86/280/EEC and amending Directive 2000/60/EC of the European Parliament and of the Council. Off. J. European Union 2008, 348, 84-97.

3. Editorial: The European Water Framework directive beyond 2010: Let actions speak louder than words. J. Environ. Monit. 2010, 12, 2204-2206.

4. Water UK Response to the Environment Agency consultation on Pollution Reduction Plans. March 2009. Available online: http://www.water.org.uk/home/policy/statements-and-responses/eaconsultation-on-pollu/water-uk-response-to--the-ea-consultation-on-pollution-reduction-programme14-april-09.pdf (accessed on 15 December 2010).

5. Neal, C.; Williams, R.J.; Bowes, M.J.; Harrass, M.C.; Neal, M.; Rowland, P.; Wickham, H.; Thacker, S.; Harman, S.; Vincent, C.; et al. Decreasing boron concentrations in UK rivers: Insight into reductions in detergent formulations since the 1990s and within-catchment storage issues. Sci. Tot. Environ. 2010; 408, 1315-1330.

6. Environment Agency. Water for life and livelihoods: River Basin Management Plan North West River Basin District 2009. Available online: http://publications.environment-agency.gov (accessed on 15 December 2010).

7. Rothwell. J.J.; Dise. N.B.; Taylor. K.G.; Allott. T.E.H.; Scholefield. P; Davies. H.; Neal. C. A spatial and seasonal assessment of river water chemistry across North West England. Sci. Total Environ. 2010, 408, 841-855.

8. Water UK website. Available online: http://www.water.org.uk/ (accessed on 15 December 2010).

9. Rothwell, J.J.; Evans, M.G.; Daniels, S.A.; Allot, T.E.H. Peat soils as a source of lead contamination to upland fluvial systems. Environ. Pollut. 2008, 153, 582-589.

10. NAEI website. Available online: http://www.naei.org.uk/ (accessed on 16 December 2010).

11. Mayes, W.M.; Johnston, D.; Potter, H.A.B.; Jarvis, A.P. A national strategy for identification, prioritisation and management of pollution from abandoned non-coal mine sites in England and Wales. I. Methodology development and initial results. Sci. Total Environ. 2009, 407, 5435-5447.

12. Mayes, W.M,; Potter, H.A.B.; Jarvis, A.P. Inventory of aquatic contaminant flux arising from historical metal mining in England and Wales. Sci. Total Environ. 2010, 408, 3576-3583.

13. Neal, C.; Robson, A.J. A summary of river water quality data collected within the Land Ocean Interaction Study: Core data for eastern UK rivers draining to the North Sea. Sci. Total Environ. 2000, 251/252, 585-666. 
14. Neal, C.; Whitehead, P.G.; Jeffery, H.; Neal, M. The water quality of the River Carron, west Cornwall, November 1992 to March 1994: The impacts of Wheal Jane discharges. Sci. Total Environ. 2005, 338, 23-39.

15. Thornton, G.J.P; Walsh, R.P.D. Heavy metals in the waters of the Nant-y-Fendrod: Change in pollution levels and dynamics associated with the redevelopment of the Lower Swansea Valley, South Wales, UK. Sci. Total Environ. 2001, 278, 45-55.

16. Rowland, A.P.; Neal, C.; Scholefield, P.; Halford, A.P.; Vincent, C.D.; Hockenhull, K. Mercury in rivers in NW England: From rural headwaters to the heartlands of the historic industrial base. J. Environ. Monit. 2010, 12, 2299-2306.

17. Neal, C.; Rowland, P.; Scholefield, P.; Vincent, C., Woods, C., Sleep, D. The Ribble/Wyre Observatory: major, minor and trace elements in rural headwaters to the industrial heartlands of the NW England historic industrial base. Sci. Total Environ. 2011, 409, 1516-1529.

18. Morrison, M.A.; Benoit, G. Filtration artefacts caused by overloading membrane filters. Environ. Sci. Tech. 2001, 35, 3774-3779.

19. Contado, C.; Blo, G.; Conato, C.; Dondi, F.; Beckett, R. Experimental approaches for size-based speciation in rivers. J. Environ. Monit. 2003, 5, 845-851.

20. Littlewood, I.G. Estimating contaminant loads in rivers: A review-IH Report 117. Institute. Hydrology, Maclean Building, Crowmarsh Gifford: Wallingford, Oxfordshire, UK, 1992; p. 17.

21. Ferguson, R.J. River loads underestimated by rating curves. Water Resour. Res. 1985, 22, 74-76.

22. Neal, C.; Smith, C.J.; Jeffery, H.A.; Jarvie, H.P.; Robson, A.J. Trace element concentrations in the major rivers entering the Humber estuary, NE England. J. Hydrol. 1996, 182, 37-64.

23. Dennis, I.A,; Coulthard, T.J.; Brewer, P; Macklin, M.G. The role of floodplains in attenuating contaminated sediment fluxes in formerly mined drainage basins. Earth Surf. Processes Landforms 2009, 34, 453-466.

24. Jarvie, H.P.; Oguchib, T.; Neal, C. Pollution regimes and variability in river water quality across the Humber catchment: Interrogation and mapping of an extensive and highly heterogeneous spatial dataset. Sci. Total Environ. 2000, 251/252, 27-43.

25. Nicholson, F.A.; Smith, S.R.; Alloway, B.J.; Carlton-Smith, C.; Chambers, C.J. An inventory of heavy metal inputs to agricultural soils in England and Wales. Sci. Total Environ. 2003, 311, 205-219.

26. Ashworth, D.J.; Alloway, B.J. Soil mobility of sewage sludge-derived dissolved organic matter, copper, nickel and zinc. Environ. Pollut. 2004, 127, 137-144.

27. Rothwell, J.J.; Evans, M.G.; Daniels, S.A.; Allot, T.E.H. Baseflow and stormflow metal concentrations in streams draining contaminated peat moorlands in the Peak District National Park (UK). J. Hydrol. 2007, 341, 90-104.

28. Shi, Z.; Allen, H.E.; Di Toro, D,.M.; Lee, S.-Z.; Meza, D.M.F.; Lofts, S. Predicting cadmium adsorption on soils using WHAM VI. J. Chemosphere 2007, 69, 605-612.

29. Neal, C.; Williams, R.J.; Bowes, M.J.; Harrass, M.C.; Neal, M.; Rowland, P.; Wickham, H.; Thacker, S.; Harman, S.; Vincent, C.; Jarvie, H.P. Decreasing boron concentrations in rivers: Insights into reductions in detergent formulations since the 1990's and within-catchment storage issues. Sci. Total Environ. 2010, 408, 1374-1385. 
30. Gault, A.G., Polya, D.A., Lythgoe, P.R. Environ. Geochem. Health 2003, 25, 77-85.

(C) 2011 by the authors; licensee MDPI, Basel, Switzerland. This article is an open access article distributed under the terms and conditions of the Creative Commons Attribution license (http://creativecommons.org/licenses/by/3.0/). 